\title{
LACK OF GOVERNANCE DURING 2000-2001 ECONOMIC CRISES IN TURKEY
}

\section{Assist. Prof. Dr. Demet ÇAK}

Department of Economics, Faculty of Economics, Istanbul University, Istanbul, Turkey

E-mail: demetcak@hotmail.com

Received December 14th, 2014; revised January 18nd, 2015

Copyright (C) 2015 Demet Cak. This is an open access article distributed under the Eurasian Academy of Sciences License, which permits unrestricted use, distribution, and reproduction in any medium, provided the original work is properly cited.

\begin{abstract}
Governance covers the quality of institutions and their effectiveness in translating policy into successful implementation. There are different types of governance such as global governance, corporate governance, regulatory governance, public sector governance, etc., however, we mainly focus on public sector's governance. In this article we will try to explain evaluation of policies the 2000 and 2001 economic crises in Turkey before and during the crisis by adding crises management policies in order to monitor good or bad governance activities.
\end{abstract}

Keywords: Governance, Crises, Public Economics, Political Economy

JEL: G30, H12, H19, P16

ÖZET

\section{0 ve 2001 EKONOMIKK KRİZLERİ DÖNEMİNDE YÖNETİŞİM EKSİKLİĞİ}

Yönetişim, bir politikanın uygulamaya geçirilme anındaki kuruluşların kallite ve etkinliklerini kapsayan bir kavramdır. Küresel yönetişim, kurumsal yönetişim, düzenleyïci yönetişim, kamu kesimi yönetişimi gibi farklı çeşitleri bulunmakla birlikte, burada daha çok kamu kesimi yönetişimi üzerinde durulmuştur. Bu çalışmada Türkiye'de 2000 ve 2001'de yaşanan economic krizler, kriz öncesi, sonrası ve kriz esnasındaki politika değişimleri değerlendirilerek, iyi ve kötü yönetişim faaliyet örnekleri izlenecektir.

Anahtar Kelimeler: Yönetişim, Kriz, Kamu Ekonomisi, İktisat Politikası 


\section{INTRODUCTION}

As a term of governance, is being increasingly used especially in the literature of public sector economics recently. Some of these usages are about the process of decision-making and the process by which decisions are implemented in public sector. In other words, governance refers to the processes in government actions and how things are done. It covers the quality of institutions and their effectiveness in translating policy into successful implementation.

There are different types of good governance interpretation, but six core principles have become widely accepted by all parties. One of the key principles of good governance is participation which refers to the degree of involvement of all stakeholders. Within this frame, taking an active and planned approach to dialogue with public is very important. Another important key is decency, can be describe as the degree to which the formation and stewardship of the rules is undertaken without harming or causing grievance to people (Haley, 2008). Third fundamental rule of good governance is transparency which is a sine qua none of almost every social event. In this rule, it is very consequential being rigorous and transparent about how decisions are taken. It also means that information is freely available and directly accessible to those who will be affected by such decisions and their enforcement. As usual, it is almost integral part of transparency is accountability that the extents to which political actors are responsible to society for what they say and do. Not only governmental institutions but also the private sector and civil society organizations must be accountable to the public and to their institutional stakeholders. Other principle of good governance is fairness, could be interpreted as the degree to which rules apply equally to everyone in society. Finally, the last pillar of good governance is efficiency that can be depicted the extent to which limited human and financial resources are applied without waste, delay or corruption or without prejudicing future generations. The concept of efficiency in the context of good governance also covers the sustainable use of natural resources and the protection of the environment.

Of course there are different types of governance such as global governance, corporate governance, regulatory governance, public sector governance, etc., however, in this article we mainly focus on public sector's governance, after mentioned other types of governance just briefly. More common terms associated with the types of governance are global governance and corporate governance.

Global governance can be define is governing without sovereign authority, relationships that transcend national frontiers. It is also means that doing internationally what governments do in their own country. (Finkelstein,1995: 367) Global governance implies a wide and seemingly ever-growing range of actors in every domain. Global economic and social affairs have traditionally been viewed as embracing primarily intergovernmental relationships, but increasingly they must be framed in 
comprehensive enough terms to embrace local and international NGOs, grassroots and citizens' movements, multinational corporations and the global capital market (Weiss, 2000).

Corporate governance is the framework of rules, relationships, systems and processes within and by which authority is exercised and controlled in corporations. It encompasses the mechanisms by which companies, and those in control, are held to account (Fishel, 2008). Corporate governance influences how the objectives of the company are set and achieved, how risk is monitored and assessed, and how performance is optimized. Effective corporate governance structures encourage companies to create value, through entrepreneurialism, innovation, development and exploration, and provide accountability and control systems commensurate with the risks involved.

The public sector governance can be combination of good features of the private sector and public sector. After this brief explanation of governance and good governance, in this article we will try to explain evaluation of policies the 2000 and 2001 economic crises in Turkey before and during the crisis by adding crises management policies in order to monitor good or bad governance activities.

\section{THE PROCESS OF THE ECONOMIC CRISES}

Before we start to evaluate 2000 and 2001 economic crises, it can be thought that it is necessary to mention about the conditions of economic crises in Turkish Economy briefly. At the end of 1999 in order to reduce chronically high inflation rate, Turkey adopted a stabilization program backed by the IMF. In fact, the program signed with the IMF was the extension of the staff monitored program that came into effect in 1998 by IMF. The main aim of the 1998 staff monitoring program was not to use of any fund from IMF, the fundamental purpose was to decrease to high inflation rate that had lain in the range of 65-90 per cent throughout the 1990s. The 1998 program was also targeted; (i)an increase in the primary surplus of the budget, (ii)a shift in the basic variables such as public sector wages, agricultural support prices so that they are raised in a line with targeted inflation rate, (iii) a supportive and closely coordinated monetary policy; (iv) structural reforms to ensure the progressive strengthening of public finances over time; and (v) stepped up privatization to lower the domestic borrowing requirement and enhance economic efficiency( Temiz, 2009). Moreover, according to the program monetary policy will be directed at sustaining the disinflation effort and, in the second half of 1998, the exchange rate will be managed in a manner consistent with the target of 50 percent wholesale price inflation by end year. As a result of the failure of the 1998 program due to the fact that the recovery cost of the 1999 earthquake, and aggravation of the Asian and Russian crises' conditions, IMF and Turkey announced a new program that had similar aims with previous one in December 1999. Program targets were set to eliminate inflation, to achieve a sustainable fiscal 
position, to establish a more equitable and efficient distribution of resources, and to increase the growth potential of the economy. Moreover, 1999 program depended on three pillars: up-front fiscal adjustment, structural reform, and a firm exchange rate commitment supported by consistent incomes policies. Up-front fiscal adjustment was also necessary because the weakness of public accounts was the ultimate factor behind high inflation. Tight fiscal and monetary policies, a structural reform and a sound exchange rate commitment were envisaged as anchors of the program which also to be backed by the Central Bank (CBRT) implementations swell (Temiz, 2009).

The Program of 1999's key fiscal goal for 2000 was to raise the primary surplus of the public sector from-2.8 percent of GNP in 1999 to 3.7 percent of GNP in 2000.In order to arrive this target, a new tax package which includes additional personal income and corporate tax payments; an additional payment of the annual motor vehicle and property taxes; a tax on mobile phone bills; and an increase in the remittances of surpluses generated by regulatory boards, approved by parliament on November 26.

The monetary and exchange rate policies were also the backbones of the program. The exchange rate policy aimed at minimizing fluctuations in the real exchange rates. In 1999, the Central Bank replaced the Deutsche mark with the euro in the basket, so that the basket consisted of USD 1.00 and EUR 0,77 . The monetary and exchange rate framework under the program conformed to these requirements. More specifically, the exchange rate framework had the following features:

The exchange rate path had been announced for the period January 1, 2000-December 31, 2000. During this period, the depreciation rate was 20 percent, equal to the target for WPI inflation. Within each month, the daily exchange rate adjustment shall remain constant. After the introduction of the new exchange rate system, the depreciation rate for the rest of December 1999 was the same as in the first part of the month.

In the period of July 2001 - December 2002, which involves the second 18 month period, transition to "band" implementation will take place and the width of said range would be increased gradually. Accordingly the width of the band was to be increased to $7.5 \%$ from July $1^{\text {st }} 2001$ to December $31^{\text {st }}$ 2001 and then to $15 \%$ by June $30^{\text {th }} 2002$ and then to $22.5 \%$ by December $31^{\text {st }} 2002$. In this "band" practice, Central Bank wouldn't interfere with the movement of the rate within the "band".

As is seen, Central Bank makes a detailed commitment regarding the future course of rates on one hand and explained the strategy to gradually get out of this commitment. With this implementation, future developments will be known and thus the uncertainty of inflation and inflation expectations 
will be minimized, also real interest rates in the economy will decrease. Therefore foreign exchange rate policy constituted the most important part of struggling with inflation.

Restriction was imposed on the net inner assets of Central Bank in the monetary policy area. Limit for net inner assets was determined at 1.2 quadrillion and increasing net inner assets in proportion to inflow of foreign currency was decided. By this way, coining of the Central Bank was limited and it was aimed for the bank to operate as a monetary committee. It was decided to reduce domestic borrowing depending on the inflow of foreign currency and to increase liquidity by releasing TL to the market and to decrease interest rates.

Also, developing an auto mechanism to keep Central Bank foreign currency reserves above a certain level was intended by introducing a target base for net international reserves.

By implementing above mentioned monetary program, CBRT was aimed to curb inflation, to increase credibility and to reduce uncertainty of the economic conditions.

The main purpose of the program is to decrease inflation, as seen in its name. The program aimed at lowering consumer price inflation to 25 per cent by 2000, to 12 per cent by 2001 and to 7 per cent by 2002 through coordinated application of finance, income, monetary and rate policies that are consistent with each other, strong, reputable and constant and supported by structural reforms. Increasing productivity of economy and making private and public sectors work better was aimed by means of decreasing inflation down to one digit numbers.

\subsection{Structural Reforms in Public Financial Sector}

Making budget adjustment policies of 2000 sustainable in mid-term, lightening the interest payment burden regarding public sector debt, increasing transparency and economic activity was aimed with structural reforms. Realization of below explained structural reforms was decided in order to provide high growth in a low-inflation environment ("IMF Enquiry Letter dated 9 December 1999")

\section{- Social Security Reform}

With the affirmed reform in September 1999 in assembly, minimum retirement age was increased as for new included ones within system it is $58 / 60$ and for currently included ones within system is $52 / 56$ with a decadal transition period. While the minimum premium payment period is increased in order to gain right for retirement, income replacement rate is decreased from $80 \%$ to $65 \%$. Reference period in calculation of retirement pension is increased as a labor period; increase in salary is connected to the consumer price index (TÜFE); and base pay ceiling of premium is 
enhanced. A common idea was formed on the subject of that unless the reform is made, security system deficit in $3 \%$ level of Gross National Product (GSMH) will become greater. Owing to the social security reform, it was expected a positive development at the rate $0,5 \%$ of GSMH in the year 2000.

\section{-Agricultural Policies}

Current agricultural support policies influenced resource allocation adversely by subverting price signals in market and it was not helpful for poor farmers but rather wealthy farmers. Besides, a consequent decision could not be made, for the decision making mechanism was dispersed among many ministries and public establishments. More importantly, in recent years, these policies place a burden to tax payers with a cost averagely $3 \%$ of GSMH. Aim of reform program in medium term is to remove current support policies segmental and form a direct income support system that aims at poor farmers.

\section{-Public Finance Management and Transparency}

Because it's the key to government's stabilization program, public finance management aimed at making significant changes to strengthen the preparation, application and controlling of a budget; to increase transparency and reliability of budget budget processes; to enhance tax system and administration. Actual scope of the budget shall be extended in order to strengthen budget control. With this purpose, it was planned for 20 of 61 budget funds to be closed until February 2000 and 25 of them until August 2000. Remaining funds shall be closed until June 2001. Either budgetary or extra budgetary, no new funds shall be created after that.

In order to maintain transparency budgetary procedures, until the end of 1999, government will take stocks of all unprompted obligations; particularly the government guarantees and will release them to the public. Again, in order to maintain transparency, credit subvention costs of state banks were included into budget of the year 2000. In 2000, IMF Fiscal Affairs Department was going to prepare a fiscal transparency report at the request of the government. This report was going to affect the situation of Turkey positively by its creditors and financial markets; also it was going to be the basis of other reforms in this field.

\section{•Reforms Regarding Banking System}

With the Banking Law numbered 4389 accepted by the Turkish Grand National Assembly on June 1999, regulation, supervision and observation authorities which were previously shared by the Under secretariat of Treasury and the Central Bank was assigned to Banking Regulatory and Supervisory Agency (BDDK). It was aimed for BDDK to be completely autonomous by leaving Council of Ministers 
out from all the decisions regarding regulation, supervision and observation except for appointing BDDK members. Especially the authorities of licensing banks, removing them and approving response regulations were completely of BDDK's. By the end of September, foreign currency net general position limit for commercial banks were decreased to $20 \%$ of their capital. For banks with capital adequacy ratios lower than minimum level required, it was obligatory to present a program related to a schedule and flow that program in order to strengthen their capital positions. Starting from 2000, BDDK was supposed to prepare trimester reports about the measures in question and banks' compatibility or incompatibility to these measures. With the Banking Law, Saving Deposit Insurance Fund was assigned with authority and responsibility regarding restructuring and selling a problematical bank or liquidating them in accordance with the statutes at large.

Strengthening solutions will be presented for long-term problems of Ziraat and Halk banks and provisions shall be made for them to operate in accordance with the market rules in parallel with ultimate privatization purposes. As of the end of $1999,15 \%$ of outstanding duty losses shall be turned into securities that bring interest income depending on CPI which will be paid in cash later. The income of the part of outstanding duty losses that haven't been turned into securities shall be calculated as the average of Treasury bill interest rates plus 35\% difference for Ziraat Bank and 21\% for Halk Bank. These differences shall be regarded as the free services that these banks provide for the state and in the future these services shall be priced more appropriately, therefore banks would have a profiting structure.

However, only 11 months after the initiation of the program, it failed with a severe liquidity shortage. In fact, on November 2000 the first of successive economic crisis hit the Turkish economy.

After the program was put into practice, developments on macro level occurred in accordance with the theoretical expectations in the first stages. In open economies - that include rate increase expectation as well - domestic borrowing interests as implied by domestic, foreign interest equity adapts to foreign exchange anchor while real interests are still high on foreign exchange level and thus capital inflows increased. But inflation receding wasn't as fast as expected. Real rates went into valuation tendency. With rapid acceleration of importation, external deficit grew into ominous sizes. Despite the strict fiscal policy, when the anticipated speed couldn't be provided at the structural measures of the program, it lost its credibility and domestic borrowing interest rates started to rise (Celasun, 2002). These developments increased the liquidity requests of the banks with a significant part of current assets consisting of treasury securities and thus in the end of November 2000, liquidity jam became exorbitant (CBT, 2001: 72). Balance fragility became more significant for some of the private banks. 
The crisis of November $22^{\text {nd }}$ was actually caused by the financial system and its main actors are the bankers. This interaction in finance markets became a full-blown crisis through triggering of the actors, the bankers. This caused banks to try and close their gap positions and public and private banks to go into debt. Beginning rise of risk premiums on Turkey's borrowing interest in foreign (Euro) markets caused the foreign borrowing of banks get difficult (Uygur, 2001:11).

Base weaknesses of the banking sector that increased in the period before the crisis can be listed as;

- Structural problems of the banks increased; administrations distant from active supervision which conflict with banking principles became widespread; the main purpose of banks became cheaply funding the capital needs of their own companies and thus the capital structure of banks became weaker.

- As a result of the gradual increase of country risk, maturity dates became shorter and interest rates increased in the debt procurement of banks. This opportunity of arbitrage caused by high real interest rates made it appealing for the banking sector to get a short-term debt from overseas and then finance public deficits with long-term Government Debt Securities. Therefore, du

e date incompatibilities emerged in the asset-liability items of the banks and deficits increased. Increasing budget deficits caused banks to become institutions that grant loans, to public sector and not the private sector. The share of domestic government bonds among total assets of deposit banks was $10 \%$ in 1990 then it escalated quickly and reached around $25 \%$ in the crisis period (BDDK "Banking Sector Reconfiguration program", 2001:6).

- Reliability and reversibility criteria became distant in loans so non-performing loans of banks increased.

- As a result of late payments of duty losses of Public Banks and assigning duties besides the principal intended actions, public banks met their financing needs from the market in short-term and with high costs and this increased the losses of the banks and caused them to become elements of instability in the financial sector. That's why the public banks were the most important cause of high interest rates in markets in the pre-crisis period. Because of this crooked structure, share of public banks, those collect $40 \%$ of total deposits in Turkey, in loans were only around 25 per cent (BDDK "Banking Sector Reconfiguration program", 2001:6).

As a result of rapidly increasing liquidity needs of banks and their pursuit of liquidity with high interest rates increased the demand for foreign exchanges and foreign banks sold their treasury securities and fled Turkey. In this environment, the most significant mistake of the Central Bank is 
that it couldn't meet the liquidity need of the market in time. This situation shook the confidence to the economic program of December $9^{\text {th }} 1999$ and the depression reflected on markets, demands decreased in the real sector and speculative approach against foreign exchange arose. Increased interest rates, currency losses, IMF loan of 7.5 Billion dollars and transfer of banks with high liquidity needs to saving deposit insurance fund partially relieved the market. To tell the truth, it supposedly relieved because three months after the crisis, triggering of speculative actions on the markets by a dispute between the Prime Minister and the President of the Republic began the currency crisis this time (Karluk, 2005:425).

During and after November, foreign exchange reserves of CBT mildly decreased. CBT lost 5.5 billion dollars of foreign exchange reserves in total, approximately 3 billion dollars between November $17^{\text {th }}$ and $24^{\text {th }}$ and 2.5 billion in November $24^{\text {th }}$-December $1^{\text {st }}$. In two weeks, gross foreign exchange reserves dropped from 24.4 billion dollars to 18.9 billion. In this way, the lower limit of net foreign exchange reserves set forth by the inflation recession program was exceeded. The quick melting of foreign exchange reserves reflected the level of pressure and tension in the financial markets. This reflection of pressure and tension to reserves started earlier, in October. Foreign exchange reserves dropped 1.8 billion dollars between October $13^{\text {th }}$ and $27^{\text {th }}$ (Uygur, 2001:4).

The nervousness of financial markets couldn't be overcome and overnight interest passed $150 \%$. Treasury bill rate of three months period left was treated around $120 \%$ and six-month-term government debt securities around $60 \%$. No matter how much tax was collected, it was far from possible to achieve the assertive goals of 2011 budget. Between November $23^{\text {rd }}$ and $29^{\text {th }}$, the Central Bank had to sell foreign exchanges over 4 billion dollars (Eğilmez, Kumcu ,2001).

\section{February 2001 Economic Crises and the 2001 Transition program to a Strong Economy}

With the February 2001 crisis, inflation-fighting program that was promulgated in December 1999 had come to an end. After the February crisis, a program that was declared on 15 May 2001 and named as Transition to The Strong Economy Program entered into force. Main difference between this recent program and 2000 inflation reduction program is that there is a currency policy based on floating rate instead of foreign exchange anchor. Other goals of the 2000 program (public sector reform, social security, privatization, agricultural reforms) are within the goals of this program as well. This program primarily set forth reforms in the banking sector. With this program, it was acknowledged that the Turkish economy had structural problems and that stable growth couldn't be maintained and that this inflationist process won't come to an end before overcoming these problems. 
In the Program for Reducing Inflation which took effect in 2000, "foreign exchange anchor" was the primary tool of reducing the inflation whereas the new program was based on "inflation targeting" for reducing the inflation. But the program designated monetary base as its mid goal whereas its implicit nominal diameter was inflation targeting.

Fight against inflation was of top priority in the program that took effect in 2000. But the crises, physical and institutional infrastructure problems showed that the economy couldn't get rid of the depressions when left in negligence. It seemed impossible to reduce the inflation and get the economy out of difficulties without bringing a healthy structure to the banking system. That's why solving the structural problems was regarded as the pre-condition of the fight against inflation in GEGP (Transition to the Strong Economy Program) (Kandilliler, 2001).

Fight against inflation shall be pursued continously and decidedly in the floating rate system. Even though in the year 2000 the lowest inflation rate of the decade was achieved, it was estimated that WPI would be $57.6 \%$ and CPI would be $52.5 \%$ in 2001 . With the Transition to the Strong Economy Program aimed CPI to be $20 \%$ in 2002 and $15 \%$ in 2003.

- Banking sector, starting with the banks within the body of public and TMSF (Saving Deposit Insurance Fund) shall be reconfigured rapidly and extensively thus a health relationship can be established between the banking sector and real sector.

- Transparency and accountability shall be procured in the public resource allocation process and governance and fight against corruption shall be consolidated.

- Public financing balance shall be strengthened through achieving noninterest surplus and then structural transitions so that it can never be corrupted again.

- An income policy based on social reconciliation, which sets forth sharing the sacrifice fairly by all the sectors and is compatible with the inflation goals, shall be maintained.

- It shall make all these happen with efficiency, flexibility and transparency and form a legal infrastructure for structural elements.

A strict political commitment and support was required to reach the goals set forth in the program and to reconfigure the economy, it was impossible to go back to the old order.

The most significant cause of the economic crises was regarded as not completely following the program equipped with the right goals. As a matter of fact, the official documents about the crisis had statements as follows: 
“...the failure of the Turkish bureaucracy to implement the necessary structurall adjustment reforms on time, thereby disturbing the market agents and letting foreign capital to leave the country." According to this view, the 2000 stabilization program was carefully thought and planned, and yet, Turkey failed to meet its targets. Thus, "the crisis is the end result of Turkey's failure to follow its program", and the problem is due to "Turkey's bad record interims of doing its homework in time, which deserves to be severely penalized"(Yeldan, 2002).

In fact, of course the only reason was not following the well-fictionalized program verbatim. The deficiency of the previous program's played an important role in Turkey's process of transition to strong economy program.

Public banks that carry the duty loss stocks in their balance sheets and doesn't receive any compensation from the budget to finance them tried to provide for their short-term financing needs from the markets and this became a problem after a while in the program. If in 2000 , before putting the program based on exchange rate into effect, similarly with the operations aimed at capitalization of public banks in 2001, financial structures of public banks could be reinforced and real rates could be reduced a bit, more advantageous starting conditions for the fight against inflation could be provided. In this respect, it can be detected that the timing of the program was rushed. Also after transiting to a risky program, regulations aimed at reinforcing the balance sheets of private banks and incorporating weak 7 banks(Before the crisis of November 2000), which pose a risk against the system, into SDIF created apprehension and caused problems that disturbed the fight against inflation.

Again the inflation goal and exchange rate commitments seemed far from possible. The program designated the WPI inflation as $20 \%$ and regulated the exchange rate table accordingly. When you consider the price consistency of sectors not subjected to foreign trade, you can see that the target set is not a very realistic one (Celasun, 2001). As a result of the aim in this direction, domestic borrowing interests rapidly dropped and this became the pride of the economic administration. Real rates went into valuation because that the inflation couldn't be reduced at the same rate.

With a similar approach, the monetary board limited the net domestic assets (NDA) of the Central Bank and left determining the interest to the market. At times of increase in capital inflow and net foreign assets (NFA) widening of monetary base reduced the interest whereas limited tools to use in times when NFA regresses significantly formed a great risk.

Too many structural regulations set forth in the program and related to the schedule and poor prioritization caused great problems. Although the short-term noninterest balance of the budget 
improved, inability to actualize the many structural regulations that are considered important by financial investors affected the credibility of the program negatively. Setting forth an impossible level for the privatization income in 2000 (cash 7.6 billion dollars) in Turkey's conditions is perceived as an element of risk for the credibility of the program. Including many micro level structural regulations that have slim chances of happening in a stability program with high-need for credibility formed an element that increases the fragility of the program.

Transition to prospective indexation for wage and price determination was an important element of 2000 program, which had an assertive target for inflation. The increase in real workforce costs of public and private sectors in 2000 indicates that the wages weren't designated supportively for the inflation reduction.

Not taking any precautions to prevent outburst in current deficit (e.g., taxation of consumer loans or additional consumption tax) is another weakness of the practice. Even though the responsibility of the program was taken by Central Bank and Treasury management selflessly, it wasn't adopted politically and transition to prospective indexation didn't happen in the private sector and for these, it was harshly criticized.

The Prime Minister's public statement about February $19^{\text {th }}$ tension as "there's a crisis" also triggered financial panic. This clarifies how much the top management perceived and paid attention to the credibility of a highly-risky and fragile program in progress. Projection and implementation weaknesses of the IMF-supported 2000 program can be evaluated from other angles. The inability to restrain the growth of current deficit presented a great weakness. Leaving the capital outflow reflected on "net fault/defect" item of capital inflows and balance of payments that finance the rapidly growing current deficit increased the risk of the program.

\section{CONCLUSION}

In the evaluation of the sequential economic crises of 2000 and 2001 in Turkey in terms of governance, it can be seen that the program that have been recommended by IMF since 1999 as a recipe for crisis is not completely compatible with the country in different angles. That's why in a short time, the crisis went deeper and created the need for a second program. When planning the crisis program, current situation weren't well-evaluated, the program took effect in a hurry without giving the public banks the opportunity to reinforce their financial structures and reducing the reel rate not even a bit. Also designating the inflation target and foreign exchange commitments away from possible created another weak spot. Again, too many structural regulations set forth in the program and related to the schedule and poor prioritization caused great problems. Not taking 
measures to reduce the rise in current deficit such as taxation of consumer loans or additional consumption tax is also another weakness in the implementation. The most significant lack of governance in the signified period is that the top of the government deepened the economic crisis by means of creating a political crisis as well in an environment of financial crisis. Thus, it appeared that the most fundamental principle of good governance, attendance to decision mechanism, wasn't adopted by the top of the government itself. 


\section{REFERENCES}

- BDDK (2001), "Banking Sector Reconfiguration Program”.

- Celasun, M. (2002), "2001 Krizi, Öncesi ve Sonrasi: Makroekonomik ve Mali Bir Değerlendirme", Küreselleşme, Emek Süreçleri ve Yapısal Uyum (Ed. A. Dikmen). Türk Sosyal Bilimler Derneği, İmge Yayınları, Ankara

- Eğilmez M., Kumcu E. (2001), Krizleri Nasıl Çıkardık, Creative Yayıncıllık, İstanbul.

- Haley, N. (2008), "Strengthening Civil Society to Build Demand for Better Governance in the Pacific Literature Review and Analysis of Good Practice and Lessons Learned", http://ips.cap.anu.edu.au/sites/default/files/SSGM_Build_Demand_Better_Governance.pdf.

- Finkelstein, L., S.(1995), "What is global governance." Global Governance 1(3).

- Fishel, D. (2008), The Book of the Board: Effective Governance for Non-Profit Organisations, Sydney.

- $\quad$ IMF Enquiry Letter dated 9 December 1999

- Kandilliler, R. (2001) “Güçlü Ekonomiye Geçiş Programı ve Ötesi”, http://www.dtm.gov.tr/ead/DTDERGI/tem2001/ekonomi.htm

- Karluk, R. (2005), Cumhuriyetin İlanından Günümüze Türkiye Ekonomisinde Yapısal Dönüşüm, Beta Yayınları, İstanbul.

- Temiz, D. (2009), "The 2000-2001 Financial Crisis in Turkey and the Global Economic Crisis of 2008-2009: Reasons and Comparisons", International Journal of Social Sciences and Humanity Studies, Vol 1, No 1.

- Uysur, E. (2001), "Krizden Krize Türkiye: '2000 Kasım Ve 2001 Şubat Krizleri”, http://www.tek.org.tr/dosyalar/KRIZ-2000-20013.pdfp.4

- Weiss, T., G. (2000), "Governance, good governance and global governance: Conceptual and actual challenges", Third World Quarterly, Volume 21, Issue 5.

- Yeldan; E. (2002), "Behind the 2000/2001 Turkish Crisis: Stability, Credibility and Governance for Whom?". Paper Presented at the IDEAs Conference, Chennai, December, http://www.bilkent.edu.tr/ yeldane/Chennai_Yeldan2002.pdf 